\title{
HEALTH AND PEACE: GLOBAL, REGIONAL AND LOCAL PERSPECTIVE
}

\author{
Akhtar Sherin $^{1 \otimes}$
}

THIS ARTICLE MAY BE CITED AS: Sherin A. Health and peace: global, regional and local perspective. Khyber Med Univ J 2018; 10(3):121-3.

$\mathrm{O}$

ver the last few decades, human beings are facing the worst challenges of violence, terrorism and wars apart from health related challenges. Health and peace are the fundamental rights of every human being and are interlinked. Relationship between health and peace is dynamic and bilateral. Peace is an important determinant of health while attainment of peace depends upon health of all people. $^{1-3}$

Both health and peace have a very broad meaning. World Health Organization (WHO) defined health as "a state of complete physical, mental and social well-being and not merely the absence of disease or infirmity". ${ }^{3}$ Similarly, "peace" is currently taken as not just the absence or reduction of war but include negation of violence, presence of harmony, justice, equity; and the capacity to handle conflict in a nonviolent manner.

Global peace is under threat by various conflicts, violence, terrorism and wars. During second half of $20^{\text {th }}$ century, power game among superpowers resulted in open warfare, cold wars and proxy wars, leading to violent conflicts across the world. Worldwide, conflicts arising from any geopolitical, ethnic, religious and economic matters are handled either by a nonviolent peaceful way or through violence and wars. The use of violence for conflict resolution and peace building is not justified as violence itself is considered as opposite to peace and peace should only be achieved by peaceful means. Violence, civil wars and terrorism are major threats to global health. Along with economic and infrastructural damage, wars contribute to increased mortality and morbidly with detrimental effects on physical and psychological health of the population. According to Global Burden of Disease
Study, wars will be the $8^{\text {th }}$ leading cause of disability and death by $2020 .^{8}$ Iraq war led to the loss of I, 16,903 Iraqi civilians and more than 4,800 coalition military personnel from 2003-1 I. In Afghanistan, conflict and terrorism is the leading cause of disability-adjusted life years (DALYs) lost.. ${ }^{10}$ Pakistan is also affected by violent conflict with an increasing trend over the last couple of decades." This resulted in 63,554 deaths in Pakistan from 2000-2018. ${ }^{2}$ The economic burden on Pakistan due to incidents of terrorism from 200I-2018 was US\$ 126.79 billion. $^{13}$

Achieving the goal of desirable standard of health for all people needs sustainable, long-term peacebuilding measures by reducing all forms of violence and wars. United Nations General Assembly in its resolution no 34/58 stated: "Peace and security, in their turn, are important for the preservation and improvement of the health of all people, and that cooperation among nations on vital health issues can contribute importantly to peace".' 14 This gigantic task needs a multidisciplinary approach and cannot be achieved without involvement of the health professionals - as highlighted by $\mathrm{WHO}$ - resolution number 34.38 in $34^{\text {th }}$ World Health Assembly. ${ }^{15}$

Various organizations like "International Committee of the Red Cross", "International Physicians for the Prevention of Nuclear War", "International Campaign to Ban Landmines" and others have worked on the involvement of health force in peace building process. $^{16}$ In 1984, Pan American Health Organization (PAHO), introduced the concept of "Health as a Bridge for Peace (HBP)" 17 which was later on adopted by $\mathrm{WHO}$ in 1998 during $51^{\text {st }}$ World Health Assembly. ${ }^{18} \mathrm{HBP}$ aimed to support the health workers in providing healthcare services in conflict affected
\ Chief Editor KMUJ; Department of Medicine, Khyber Medical University Institute of Medical Sciences, Kohat, Pakistan

Email:akhtarsherin@yahoo.com

zones and simultaneously avail all the opportunities to promote peace through various health related activities. ${ }^{19}$ Health related initiatives are not only helpful in reducing morbidity and mortality during wars but can also be useful in prevention, resolution and transformation of conflicts before, during and after violent conflicts and wars.

"Peace through health $(\mathrm{PtH})$ " is another important peace work initiative from McMaster University, addressing the role of health workers in promoting peace through various health interventions in context of war and conflict. $^{16,20,21} \mathrm{PtH}$ working group has identified various mechanisms that can explain the peace-work performed by health-workers. ${ }^{21,22}$ Health professionals are already equipped with knowledge, certain skills, values and qualities that can be utilized in handling violent conflicts and promotion of peace in many situations. 5.16

Like any other program, there are some limitations of $\mathrm{PBH} \& \mathrm{PtH}$ programs as well. There is no evidence-based, systematic evaluation of the impact of peace through health initiatives. ${ }^{16,23}$ Some quarters advocate that health professionals are only concerned with health care delivery in war-affected areas and should not be involved in conflicts and peace building process. Neutrality and impartiality of healthcare workers in certain situations can also be compromised. Questions are also being raised regarding formal education and appropriate skills of health care workers in conflict management and peacebuilding process. ${ }^{16,24-26}$ However, the usefulness of peace through health theory has not been refuted through solid evidence. ${ }^{20}$

As already discussed, South Asian region, including Pakistan and Afghanistan are confronting violent conflicts, wars and terrorism during the recent past. There is a dire need of seeking every opportunity to achieve and promote peace in Pakistan, Afghanistan and the 
region. The involvement of health professionals in this highly needed and noble cause is a proven and viable strategy. A strategic plan may be developed for integration of health-care delivery system with the prevention and transformation of violent conflicts and wars. Special peace-based training courses should be arranged for health care providers in war affected areas and high intensity conflict zones. Incorporation of peace and conflict studies in undergraduate medical curriculum and postgraduate publichealth curriculum at university level will be a way forward in achieving peace through health in Pakistan and the region.

\section{REFERENCES}

I. MacQueen G, Santa-Barbara J. Peace building through health initiatives. $\mathrm{Br}$ Med J $2000 \mathrm{Jul}$ 29;32I (7256):293-6.

2. Canadian Nursing Association. Peace and health. Fact sheet. [Cited on: June 26, 2018]. Available from URL: https://www.cna-aiic.ca/ / media/cna/page-content/pdffr/fs27_peace_health_2009_e.pdf

3. Preamble to the Constitution of $\mathrm{WHO}$ as adopted by the International Health Conference, New York, 19 June - 22 July 1946; signed on 22 July 1946 by the representatives of 6 I States (Official Records of WHO, no. 2, p. 100)

4. Webel C. Introduction: Toward a philosophy and metapsychology of peace. Chap I. In: Webel C, Galtung J, (Ed). Handbook of Peace and Conflict Studies. Oxford, UK: Routledge, 2007, p3.

5. Salvage J, Rowson M, Melf K (Eds). The Medical Peace Work textbook. 2012. $2^{\text {nd }}$ edition, Course I: Health workers, conflict and peace. London, Medact. [Cited on: June 26, 2018]. Available from URL: www.medicalpeacework.org

6. Galtung J. Peace by peaceful means: peace and conflict, development and civilisation. London, 1996. Prio/Sage
7. Kerridge BT, Khan MR, Sapkota A. Terrorism, civil war, one-sided violence and global burden of disease. Med Confl Surviv 2012 JulSep;28(3): 199-2।8.

8. Murray CJ, Lopez AD. Alternative projections of mortality and disability by cause 1990-2020: Global Burden of Disease Study. Lancet 1997 May 24;349(9064): | 498-504. DOI: I0.1016/S0|40-6736(96)07492-2

9. Levy BS, Sidel WW. Adverse health consequences of the Iraq War. Lancet 2013 Mar 16;38I(9870): 949-58. DOI: $10.1016 / 50140$ 6736 (I3)60254-8.

10. Massahikhaleghi P, TehraniBanihashemi A, Saeedzai SA, Hossaini SM, Hamedi SA, MoradiLakeh $\mathrm{M}$, et al. Burden of diseases and injuries in Afghanistan, 19902016: Findings from the Global Burden of Disease 2016 Study. Arch Iran Med 20 I 8;2I (8):324-34.

II. Saeed L, Syed SH, Martin RP. Historical patterns of terrorism in Pakistan. Defense Secur Anal 2014; 30(3): 209-29. DOI: 10.1080/ |475|798.20|4.92|450.

12. South Asia Terrorism Portal (SATP). Fatalities in Terrorist Violence in Pakistan 2000-2018. [Cited on: September 25, 2018]. Available from URL: http:// www.satp.org/ satporgtp/countries/pakistan/ database/casualties.htm.

13. Government of Pakistan. Ministry of Finance (20I8). Impact of War in Afghanistan and Ensuing Terrorism on Pakistan's Economy. AnnexureIV. Pakistan Economic Survey 201718. [Cited on: September 25, 20 I8]. Available from URL: http://www. finance.gov.pk/survey/chapters I8/ Annex IV Impact\%20of\%20War pdf.

14. United Nations General Assembly. Resolution adopted by the General Assembly: 34/58. Health as an integral part of development. 29 November 1979. [Cited on: June 26, 2018]. Available from URL: http://www.un-documents.net/ a34r58.htm.
15. World Health Organization. Thirty Fourth World Health Assembly. Resolutions and decisions-Annexes. WHA34.38 The role of physicians and other health workers in the preservation and promotion of peace as the most significant factor for the attainment of health for all. GENEVA, 4 -22 MAY 198I. [Cited on: June 26, 2018]. Available from URL: http:// apps.who.int/iris/ bitstream/handle/I0665/I55679/W HA34_I 98 I-REC-I_eng.pdf? sequence $=\mid$ \&isAllowed $=y$.

16. Arya N. Peace through Health? Chap 24. In: Webel C, Galtung J (Ed). Hand-book of Peace and Conflict Studies. Oxford, UK: Routledge, 2007, p. 367.

17. de Quadros CA, Epstein D. Health as a bridge for peace: PAHO's experience. Lancet 2002 Dec;360 Suppl:s25-6. DOI: 10.1016/SOI406736(02)। I808-3.

18. World Health Organization. 4.I Health-for-all policy for the twentyfirst century (Resolution WHA5I.7). Resolutions and other actions of the fifty-first world health assembly of interest to the PAHO executive committee. Geneva, Switzerland, May 1998. [Cited on: June 26, 2018]. Available from URL: http://iris.paho.Org/xmlui/ bitstream/handle/I $23456789 /$ 20954/doc523.pdf?sequence $=$ I \&is Allowed $=y$.

19. World Health Organization. Health as a bridge for peace: report on the First World Health Organization Consultative Meeting, October 30 3I, 1997. [Cited on: June 26, 20 I8]. Available from URL: http:// www.who.int/hac/techguidance/hb p/strategies_/en/indexl.html.

20. Arya N. Peace through health I: development and use of a working model. Med Confl Surviv 2004 JulSep;20(3):242-57.

21. Barbara JS, MacQueen G. Peace through health: key concepts. Lancet 2004;364(9431):384-6, DOI: I0.10I6/S0I40-6736(04) 16729-9

22. MacQueen G, McCutcheon R, 
Barbara JS. The use of health initiatives as peace initiatives. Peace Change 1997;22(2): 175-97.

23. Vass AJ. Peace through health: this new movement needs evidence, not just ideology. $\mathrm{Br}$ Med J 2001;323:1020. [Cited on: June 26, 2018]. Available from URL: http://bmj.bmjjournals. Com/cgi/ content/full/323/7320// 020 .

24. Buhmann CB. The role of health professionals in preventing and mediating conflict. Med Confl Surviv 2005 Oct-Dec;2I(4):299. 3 I I. DOI: I0. I080/I36236905002 68865.
25. Barbara JS. Medicine, Peace, and Public Policy. Croat Med J 2006;47:352-5.

26. Pinto AD. Peace Through Health. Univ Toronto Med J 2003;80(2): 158-60.
CONFLICT OF INTEREST

Author declared no conflict of interest GRANT SUPPORT AND FINANCIAL DISCLOSURE

NIL 